\title{
1 Optimization of anaerobic hydrogen and methane production from dairy processing waste using a two-stage digestion in induced bed reactors (IBR)
}

Jianming Zhong a, David K. Stevens a , Conly L Hansen ${ }^{b}$,*

a Utah Water Research Laboratory, Utah State University, Logan, UT, 84322-8200,USA

b Department of Nutrition, Dietetics \& Food Sciences, Utah State University, Logan, UT, 84322-8700, USA

\section{Abstract}

This study investigated the effects of $\mathrm{pH}$, temperature and hydraulic retention time (HRT) and organic loading rate (OLR) on hydrogen production from dairy processing waste (DPW) in semicontinuous $60 \mathrm{~L}$ pilot induced bed reactors (IBR). Results show $\mathrm{pH}$ played a key role on hydrogen production and the optimal $\mathrm{pH}$ range was in 4.8-5.5. Digestion under thermophilic temperatures $\left(60^{\circ} \mathrm{C}\right)$ had advantages of gaining higher hydrogen yield and suppressing the growth of methanogens. The optimal OLR was $32.9 \mathrm{~g}$-COD/l-d at HRT of 3 days. Under optimal conditions highest hydrogen yield was $160.7 \mathrm{ml} / \mathrm{g}$-COD removed with 44.6\% COD removal. Two-stage digestions demonstrated more energy gain from methane production and further COD removal. The overall gas production in two-stage digestion was $71.7 \mathrm{ml}$ hydrogen and $61.0 \mathrm{ml}$ methane per gram DPW COD. The overall COD removal under optimal conditions was $88.2 \%$.

\section{Keywords:}

Hydrogen production, Dairy processing waste (DPW), Induced bed reactor, Two-stage digestion

\section{Introduction}

Hydrogen is considered an alternative fuel of great potential. It is environmentally friendly because only water is produced when it is combusted, and was identified as a clean energy carrier for the future at the first World Hydrogen Conference [1]. Hydrogen has an energy density of $143 \mathrm{MJ} / \mathrm{kg}$,

*Corresponding author, NDFS, Utah State University, Logan, UT, 84322, USA. Tel:+1-435 7972188

E-mail address: conly.hansen@usu.edu 
which is 2.6 times higher than methane and 3.3 times higher than gasoline. Hydrogen has great potential to reduce the use of fossil fuels. However, in industry, the majority of hydrogen is produced from fossil-fuel sources such as: natural gas, oil, and coal [2].

Dairy processing waste (DPW) is the waste produced from manufacturing dairy products: cheese, yogurt, ice cream, milk, butter, etc. DPW is high in chemical oxygen demand (COD) due to its lactose, fat and protein content, and therefore needs to be appropriately treated. The discharge of excess amounts of DPW, such as cheese whey, onto land can damage the chemical and physical structure of soil, pollute groundwater and may also affect air quality $[3,4]$. Now there are more and more whey protein concentrate and isolate products [5], which has reduced DPW quantities. However, finding a novel, cost-effective disposal or utilization technology for waste has been an important issue for the dairy industry because of:

1) still high lactose content in DPW;

2) high investment cost in whey protein processing equipment;

3) increased volume of dairy processing byproducts;

4) increasingly strict legislative requirements.

Anaerobic digestion is a potential technology for both hydrogen production and food waste management. Anaerobic digesters can produce energy from inexpensive and renewable energy sources such as food processing waste. Recent research proved that certain strains of bacteria (e.g., bacteria from the genus Clostridium) are particularly effective at producing hydrogen as a byproduct during anaerobic digestion of organic waste material [6]. Although various studies have been done on producing hydrogen with anaerobic digestion, there are still several obstacles that must be overcome before applying this technology economically at an industrial level. Induced bed reactors (IBR) are designed specifically for anaerobic digestion[7], and IBR has the ability of handling short HRT digestion of many organic wastes that may contain high un-dissolved solids [8, 9]. This may make it a very good digester for hydrogen production because studies show low HRT is typically required for hydrogen production $[10,11]$.

Recent studies have shown production of hydrogen and methane anaerobically from wastes organics in two-stage systems; for example, $[12,13]$ show hydrogen and methane can be produced using cheese whey. Other materials such as cassava wastewater[14] and sweet sorghum[15] can also be used to produce hydrogen and methane. In those studies UASB or CSTR digesters were used. However, no research has been reported using the substrate DPW. In the dairy industry large amounts of DPW, which has high content of fat, protein and lactose and may contain cleaning chemicals, is produced. And no published anaerobic hydrogen production study is based on IBR digester. In this research, single-stage digestions were performed first in $60 \mathrm{~L}$ pilot IBRs to explore the optimal conditions of $\mathrm{pH}$, temperature and HRT/OLR for hydrogen production from DPW. Later under optimal hydrogen production conditions, a second unit IBR was added for testing the performance of methane production from the effluent of the hydrogen reactor.

\section{Material and Methods}

\subsection{Substrate and seed}


DPW was provided by Aggie Creamery (Utah State University, Logan). DPW is a mix of dairy production wastes. About $40-50 \%$ (by volume) of DPW is cheddar cheese whey; $50-55 \%$ of DPW is the waste from the production of ice cream, yogurt and milk; and about 5\% is rinsing wastewater. DPW was stored at $4{ }^{\circ} \mathrm{C}$ before use. Its characteristics are presented in Table 1.The inoculum was from the sludge of an anaerobic digester that was used for biogas production from algae in Logan Wastewater Treatment Facility (Logan, UT).

\subsection{Experiment set-up}

Two 60 L IBRs were constructed and installed. To enrich hydrogen-producing bacteria and inactivate methanogens, a $25 \mathrm{~L}$ inoculum was mixed with 20-25 L DPW in a $60 \mathrm{~L}$ IBR to reach the $\mathrm{pH}$ of 5.0-5.5. Then the mixture (inoculum sludge and DPW) was heat-treated $\left(65^{\circ} \mathrm{C}\right)$ overnight.

Single-stage digestion: two duplicate IBRs were used for optimization of hydrogen production from DPW (Figure 1). Three different parameters: temperature, $\mathrm{pH}$, and HRT were examined. One IBR was set at temperature of $40{ }^{\circ} \mathrm{C}$ and another was set at $60^{\circ} \mathrm{C}$ (due to the heat loss during transfer, liquid temperatures in the central digester areas were $37-38^{\circ} \mathrm{C}$ and $55-58^{\circ} \mathrm{C}$, respectively). Three pH ranges (4.0-4.5, 4.8-5.3 and 5.5-6.0) and three HRT values (1, 3 and 5 days) were tested in a 3 factor full factorial design. Each digestion run lasted at least two weeks to obtain steady-state at $\geq 4$ times the HRT.

The two-stage digestion setup is illustrated in Figure 1. The two-stage system had a 60 L hydrogen IBR and a $60 \mathrm{~L}$ methane IBR. The effluent of the hydrogen IBR was used as influent for the methane IBR. The hydrogen IBR was operated under the optimal $\mathrm{pH} / \mathrm{HRT} /$ temperature conditions found in the single-stage digestion preliminary trials. The second stage methane digester was operated at $\mathrm{pH}$ of 6.8-7.5 and temperature of $40^{\circ} \mathrm{C}$. The inoculum for the methane IBR was from the same sludge source (Logan wastewater treatment facility), but without heat treatment.

\subsection{IBR operation}

Temperature was monitored and controlled with Cole-Parmer 16B-33 controllers (Vernon Hills, IL) and heating cable (Mor Electric Heating Assoc., Comstock Park, MI). pH could be controlled with controllers (Model 350, Cole-Parmer, Vernon Hills, IL) and associated peristaltic pumps (ColeParmer 7553-80) to keep $\mathrm{pH}$ within \pm 0.1 of the set point in the digesters by adding sodium hydroxide solution ( 1 mole/L) in the hydrogen IBR. No chemical was needed for $\mathrm{pH}$ adjustment in the methane IBR. Feed rate was automated with timers (Model R-94400-62, Cole Parmer, Vernon Hills, IL) and electrically-controlled valves (Model P251SS-120-A, Ingersoll Rand, Dublin, Ireland) that regulated air supply to a diaphragm pump (ARO 1", Ingersoll Rand, Dublin Ireland). The IBRs were fed every four hours.

\subsection{Analytical methods}

Total solids (TS) and volatile solids (VS) were measured by standard methods (APHA, 1998). Total chemical oxygen demand (COD), total organic carbon (TOC), total nitrogen (TN) and total ammonia $\left(\mathrm{NH}_{4}-\mathrm{N}\right)$ were analyzed using Hach test kits (Hach DR/870). Biohydrogen and biogas production were measured by mass flow meters (Model 822-L, Sierra, Monterey, CA). Data for gas flow rate were saved every five minutes using a datalogger (CR 1000, Campbell Scientific, Logan, UT). Biogas and biohydrogen composition were analyzed in an Agilent 6890 GC using an RT-M sieve 5A Plot capillary column (Restek) (Agilent, Santa Clara, CA). The statistics analyses were performed in R software (version 3.0.3) [16]. 


\section{Results and discussion}

\section{1. $\quad$ Single-stage digestion}

Three parameters temperature, $\mathrm{pH}$, and HRT were examined for optimization of hydrogen production from DPW. Values of temperature, $\mathrm{pH}$, HRT and OLR in each experimental run are listed in Table 2. The results of COD removal, hydrogen yield, hydrogen content, and methane content in nine experimental runs are shown in Figure 2. The statistical significance of these three parameters on COD removal, hydrogen yields, hydrogen content, and methane content was analyzed by analysis of variance (ANOVA).

\subsubsection{Effects of pH on hydrogen production}

Keeping $\mathrm{pH}$ in certain range is crucial during semi-continuous or continuous digestion operation. $\mathrm{pH}$ should be in the range 6.8-7.5 for single stage methane anaerobic digestion [17]. Three $\mathrm{pH}$ ranges (4.0-4.5, 4.8-5.5 and 5.6-6.0) were tested to examine effect on hydrogen production from DPW. As listed in Table 2, experiments I, II and III were run in the pH range of 4.0-4.5; experiments IV, V and VI were run in the $\mathrm{pH}$ range of 4.8-5.5; and experiment VII, VIII and IX were run in the $\mathrm{pH}$ range 5.6-6.0. As shown in Figure 2, digestions in the $\mathrm{pH}$ range 4.8-5.5 had higher COD removal/hydrogen yield/hydrogen content and lower methane content than the digestions in the other two $\mathrm{pH}$ ranges. The highest hydrogen yield- $160.7 \mathrm{ml} \mathrm{H}_{2} / \mathrm{g}$-COD removed; highest COD removal$44.6 \%$, and highest hydrogen content- $50.2 \%$ and lowest methane content- $2.8 \%$ were all obtained in the 4.8-5.5 pH range. Statistical significance results show $\mathrm{pH}$ had significant impacts on COD removal, hydrogen yield, hydrogen content and methane content (ANOVA, $p<0.05$ ). Such results were expected because the $\mathrm{H}^{+}$in the extracellular environment selects the bacteria that can survive at this $\mathrm{pH}$ range, and at the same time suppresses or kills other organisms that cannot grow [18, 19] . Different $\mathrm{pH}$ ranges may result in different pathways during the complex digestion process. Although methanogens were killed or inactivated during seed preparation (see Material and Methods), in the pH range 5.6-6.0 some methanogens eventually grew in the later period of our semi-continuous digestions. That might be why the methane content was higher than for $\mathrm{pH}$ ranges 4.0-4.5 and 4.8-5.5 (Figure 2). Growing methanogens may have rapidly consumed the produced hydrogen, which led to a low hydrogen yield. At pH 4.0-4.5 methane content was relatively low, which suggests a good suppression of methanogens. However, low COD removal and hydrogen yield may suggest that this $\mathrm{pH}$ range also suppresses the growth of hydrogen-producing bacteria. 4.8-5.5 was the optimal $\mathrm{pH}$ range for not only the growth of hydrogen producing bacteria but also the suppression of methanogens. Similar results were obtained by other studies using different substrates [20-23]. In order to increase the $\mathrm{pH}$ sodium hydroxide was used, which is expensive for applying to full-scale digestion. Cheap $\mathrm{pH}$ buffer addition should be considered and investigated in future research.

\subsubsection{Effects of HRT/OLR on hydrogen production}

Organic concentration of DPW was $98.7 \mathrm{~g}$-COD/l. When HRTs were kept at 1, 3 and 5 days, the OLR rates were $98.7 \mathrm{~g}-\mathrm{COD} / \mathrm{l}-\mathrm{d}, 32.9 \mathrm{~g}-\mathrm{COD} / \mathrm{l}-\mathrm{d}$ and $19.74 \mathrm{~g}$-COD/l-d, respectively. As listed in Table 2, experiments I, IV and VII were run with 1 day HRT (98.7 g-COD/l-d); experiments II, V and VIII were run with 3 days HRT (32.9 g-COD/l-d), and experiments III, VI and IX were run with 5 days HRT (19.74 g-COD/l-d). Statistical analyses showed HRT/OLR had significant impacts on COD removal and hydrogen yield (ANOVA, $p<0.05$ ), but not on hydrogen content and methane content 
(ANOVA, $p>0.05$ ). As shown in Figure 2, under the optimal $\mathrm{pH}$ range 4.8-5.5, when HRT increased from 1 to 3 days (OLR decreased from 98.7 to $32.9 \mathrm{~g}$-COD/l-d ) the hydrogen yield increased from 111.4 to $160.7 \mathrm{ml} \mathrm{H}_{2} / \mathrm{g}$-COD removed at $60{ }^{\circ} \mathrm{C}$; when HRT increased from 3 to 5 days (OLR decreased from 32.9 to $19.74 \mathrm{~g}$-COD/l-d ) the hydrogen yield decreased from 160.7 to $131.5 \mathrm{ml} \mathrm{H} / \mathrm{g}$-COD removed at $60{ }^{\circ} \mathrm{C}$. Accordingly, the highest COD removal $-44.6 \%$ was obtained in 3 days HRT compared to $40.2 \%$ in 1 day HRT and $42.6 \%$ in 5 days HRT. These results suggest that too high or too low HRT/OLR is not optimal for hydrogen production.

Different substrates may affect the optimal HRT/OLR because of their characteristics. Here, DPW has high organic content (mainly lactose) and very low non-biodegradable solids. When using another substrate that has relatively low organic content, the optimal HRT/OLR may be different $[18,24-26]$. Other factors that might be considered are feeding type: batch, continuous or semicontinuous operation. In our study, DPW was pumped every 4 hours. The optimal HRT/OLR might be different due to less impact to sludge bed when fed continuously.

\subsubsection{Effects of temperature on hydrogen production}

Each experimental run was performed under both mesophilic $40{ }^{\circ} \mathrm{C}$ and thermophilic temperatures $60^{\circ} \mathrm{C}$. Statistics analyses show temperature had significant impact in hydrogen yield, COD removal and methane content $(p<0.05)$, but not in hydrogen content. As shown in Figure 2, hydrogen yields were higher at $60^{\circ} \mathrm{C}$ than at $40^{\circ} \mathrm{C}$ expect experiment I (no significant difference in I). The largest difference was obtained in experiment VI, where $131.5 \mathrm{ml} \mathrm{H}_{2} / \mathrm{g}$-COD removed at $60^{\circ} \mathrm{C}$ versus $116.5 \mathrm{ml}$ $\mathrm{H}_{2}$ /g-COD removed at $40{ }^{\circ} \mathrm{C}$. Also in experiment VI, COD removal was $8 \%$ higher at $60^{\circ} \mathrm{C}$ than at $40{ }^{\circ} \mathrm{C}$. These results were expected because increasing the temperature typically can enhance the activity of the enzymes until the optimal temperature is reached[27]. Another advantage of thermophilic digestion is increased solubility of some polymeric substrates. Thermophilic temperature digestion is suitable for some biomass containing substances that are difficult to hydrolyze, e.g., lignocelluloses[28]. Moreover, the methane content was lower at $60^{\circ} \mathrm{C}$ than at $40{ }^{\circ} \mathrm{C}$ (Figure 2), especially in the $\mathrm{pH}$ range 5.6-6.0. This result indicates that $60^{\circ} \mathrm{C}$ had a better suppression of methanogens than $40^{\circ} \mathrm{C}$. Combined with the previous $\mathrm{pH}$ results, it is concluded that $\mathrm{pH}$ and temperature are two important factors that keep methane content low during hydrogen production. In the $\mathrm{pH}$ range 4.8-5.5 and 3 days HRT, our results showed $40^{\circ} \mathrm{C}$ digestion had low methane content and relatively high hydrogen yield and COD removal as well. Thus, $40{ }^{\circ} \mathrm{C}$ is also feasible for hydrogen production from DPW when the digestions are operated under the optimal pH range and HRT/OLR.

\subsection{Two-stage digestion}

\subsubsection{Methane production performance}

In single-stage hydrogen production the highest COD removal was $44.6 \%$. There is still high COD in the effluent of hydrogen production. Further treatment is necessary before being discharged. Twostage digestion was performed to produce both hydrogen and methane. The hydrogen IBR was operated under optimal conditions ( 3 days HRT $/ 32.9 \mathrm{~g} / \mathrm{l}-\mathrm{d} \mathrm{OLR} / \mathrm{pH}$ of $4.8-5.5 / 60^{\circ} \mathrm{C}$ ) that were found in previous single-stage digestion. The effluent of the hydrogen production was used as influent for methane production (Figure 1). Table 3 lists the results of methane production in the second stage. Four different HRTs $(8,12,15$ and 20 days) were tested. COD removals in the four different HRTs were all above 50\%. With the increase in HRT the COD removal increased. Over 70\% COD removal was achieved when HRT reached 15 days or higher. $\mathrm{pH}$ inside the IBR were all 6.8-7.5, which was the optimal range for methane production. No chemical was needed for controlling $\mathrm{pH}$ in the methane IBR. Two-stage digestion had an advantage because chemical or buffer is usually 
required to increase $\mathrm{pH}$ when digesting DPW in single-stage digestion[29]. The methane yields were 168.8-178.1 $\mathrm{ml} \mathrm{CH}_{4} \mathrm{ml} / \mathrm{g}$-COD removed. The highest methane yield was found with HRT 15 of days. The methane content was in the range of $60-65 \%$.

\subsubsection{Overall performance}

The overall performance of two-stage digestion was evaluated. Table 4 summaries the two-stage digestion under the optimal condition for hydrogen production and 15 days HRT for methane production. COD removal of $88.2 \%$ was reached in overall two-stage digestion. The effluent COD was as low as $11.7 \mathrm{~g} / \mathrm{l}$ compared to the original DPW- 98.7g/l. Furthermore, after thermophilic treatment in the hydrogen IBR the effluent will have less pathogens [30]. It is safer to reuse or dispose the effluent. It should be noted that the methane IBR's operation is very flexible. Many HRTs/OLRs can be set without affecting pH inside the digester (Table 3). Higher HRT in the methane IBR means more complete digestion. For getting maximal energy and COD removal a larger volume methane IBR size compared to the hydrogen IBR is recommended in order to make a correspondingly higher HRT. As listed in Table 4 one gram COD of DPW can produce $71.7 \mathrm{ml} \mathrm{H}_{2}$ and $61.0 \mathrm{ml} \mathrm{CH}_{4}$. Compared to hydrogen single-stage digestion, $238.9 \mathrm{~kJ}$ more energy in heating value was produced in two-stage digestion of one gram DPW COD. Thus, it can be concluded for hydrogen production that using two-stage anaerobic process provides higher energy than using a single-stage anaerobic digestion.

Table 5 compares this study with some other previous research. It should be noticed that among all the results listed in Table 5[13, 14, 31], our $60 \mathrm{~L}$ pilot-scale research had much larger digester size. Thus, our studies could be closer to large-scale digestion. Compared to other cheese whey twostage digestions, this research had significantly higher hydrogen yield than that of two-phase mesophilic UASB process at an organic loading rate of $47.4 \mathrm{~g}$ COD/l-d $\left(160.7 \mathrm{ml}-\mathrm{H}_{2} / \mathrm{g}-\mathrm{COD}\right.$ removed versus $41 \mathrm{ml}^{-\mathrm{H}_{2} / \mathrm{g}-\mathrm{COD}}$ removed [31]. The hydrogen production rate from this study was lower than that of mesophilic CSTR process at an organic loading rate of $182 \mathrm{~g}$ COD/l-d; because the CSTR hydrogen process had much higher OLR (182 g COD/l-d versus $32.8 \mathrm{~g}$ COD/l-d) and much lower HRT ( 0.25 d versus $3 \mathrm{~d}$ )[13]. Within the same thermophilic hydrogen two-stage digestion, our results were very similar to the two-stage cassava wastewater digestion in terms of hydrogen yield, methane yield and overall COD removal[14].

\section{Conclusions}

In this study, optimization of anaerobic hydrogen production from DPW was explored in semicontinuous pilot-scale (60 L) IBRs. We found the optimal conditions for hydrogen production from DPW were: HRT 3 days / OLR 32.9 g-COD/l-d, pH range of 4.8-5.5, and $60{ }^{\circ} \mathrm{C}$. Under these conditions, the highest hydrogen yield was $160.7 \mathrm{ml} / \mathrm{g}$-COD removed, highest COD removal was $44.6 \%$ and highest hydrogen content $50.2 \%$ was achieved. Two-stage digestions were tested later for further energy extraction and COD removal. Results show two-stage production of hydrogen and methane can greatly increase the amount of energy harvested and will increase COD removal. With an HRT of 15 days in the methane IBR, methane yield was $178.1 \mathrm{ml}$ methane per gram COD removed and COD removal was $73.1 \%$. The overall gas production in two-stage digestion was $71.7 \mathrm{ml} \mathrm{H}_{2}$ and $61.0 \mathrm{ml} \mathrm{CH}_{4}$ per gram COD loaded. And the overall COD removal was as high as $88.2 \%$. This study demonstrated that the production of both hydrogen and methane can be efficiently coupled in a two-stage IBR digestion system. The pilot-scale research here provides the data and design requirements for full-scale application. 


\section{Acknowledgements}

The authors would like to acknowledge the financial support of the Utah Agricultural Experiment Station (Logan, Utah) and the USDA. The authors would also like to thank Aggie Creamery at Utah State University for providing dairy processing waste, Logan Wastewater Treatment Facility for providing the seed sludge and Carl Hansen's help in installing and operating the IBRs.

\section{References}

[1] Lattin W, Utgikar V. Transition to hydrogen economy in the United States: a 2006 status report. International Journal of Hydrogen Energy. 2007;32:3230-7.

[2] O'M Bockris J. On hydrogen futures: toward a sustainable energy system. International Journal of Hydrogen Energy. 2003;28:131-3.

[3] Ben-Hassan RM, Ghaly AE. Continuous propagation ofKluyveromyces fragilis in cheese whey for pollution potential reduction. Applied Biochemistry and Biotechnology. 1994;47:89-105.

[4] Bullock DK, Hansen CL, Poe SE. Carbon monoxide production from land applied cheese whey. Bioresource Technology. 1995;54:231-3.

[5] Alves M, Moreira RdO, Rodrigues Júnior P, Martins MdF, Perrone Í, de Carvalho A. Whey: technologies for coproducts production. Revista do Instituto de Laticínios Cândido Tostes. 2014;69:212-26.

[6] Zhang H, Bruns MA, Logan BE. Biological hydrogen production by Clostridium acetobutylicum in an unsaturated flow reactor. Water Research. 2006;40:728-34.

[7] Hansen CL, Hansen CS. Induced sludge bed anaerobic reactor. Google Patents; 2005.

[8] Hansen CL. Completely Stirred Tank Reactor Behavior in an Unmixed Anaerobic Digester: The Induced Bed Reactor. Water Environment Research. 2012;84:711-8.

[9] Dustin J, Hansen C, Dustin J. Field performance of the induced bed reactor anaerobic digester. Applied Engineering in Agriculture. 2011;27:373-7.

[10] Wang J, Wan W. Factors influencing fermentative hydrogen production: A review. International Journal of Hydrogen Energy. 2009;34:799-811.

[11] Hawkes F, Dinsdale R, Hawkes D, Hussy I. Sustainable fermentative hydrogen production: challenges for process optimisation. International Journal of Hydrogen Energy. 2002;27:1339-47. [12] Venetsaneas N, Antonopoulou G, Stamatelatou K, Kornaros M, Lyberatos G. Using cheese whey for hydrogen and methane generation in a two-stage continuous process with alternative $\mathrm{pH}$ controlling approaches. Bioresource technology. 2009;100:3713-7.

[13] Cota-Navarro C, Carrillo-Reyes J, Davila-Vazquez G, Alatriste-Mondragón F, Razo-Flores E. Continuous hydrogen and methane production in a two-stage cheese whey fermentation system. Water Science and Technology. 2011;64:367.

[14] Intanoo P, Rangsanvigit P, Malakul P, Chavadej S. Optimization of separate hydrogen and methane production from cassava wastewater using two-stage upflow anaerobic sludge blanket reactor (UASB) system under thermophilic operation. Bioresource technology. 2014;173:256-65. [15] Antonopoulou G, Gavala HN, Skiadas IV, Angelopoulos K, Lyberatos G. Biofuels generation from sweet sorghum: fermentative hydrogen production and anaerobic digestion of the remaining biomass. Bioresource technology. 2008;99:110-9. [16] R Development Core Team. R: A language and environment for statistical computing. Vienna, Austria: R Foundation for Statistical Computing; 2014. 
[17] Martin A. Understanding Anaerobic Digestion. Presentation to the Environmental Services Association. 2007;16.

[18] Fang HH, Liu H. Effect of pH on hydrogen production from glucose by a mixed culture. Bioresource Technology. 2002;82:87-93.

[19] Temudo MF, Kleerebezem R, van Loosdrecht M. Influence of the $\mathrm{pH}$ on (open) mixed culture fermentation of glucose: a chemostat study. Biotechnology and bioengineering. 2007;98:69-79. [20] Luo G, Xie L, Zou Z, Wang W, Zhou Q. Exploring optimal conditions for thermophilic fermentative hydrogen production from cassava stillage. International Journal of Hydrogen Energy. 2010;35:6161-9. [21] Sompong O, Prasertsan P, Intrasungkha N, Dhamwichukorn S, Birkeland N-K. Improvement of biohydrogen production and treatment efficiency on palm oil mill effluent with nutrient supplementation at thermophilic condition using an anaerobic sequencing batch reactor. Enzyme and microbial technology. 2007;41:583-90.

[22] Oh YK, Kim SH, Kim MS, Park S. Thermophilic biohydrogen production from glucose with trickling biofilter. Biotechnology and bioengineering. 2004;88:690-8.

[23] Sreethawong T, Chatsiriwatana S, Rangsunvigit P, Chavadej S. Hydrogen production from cassava wastewater using an anaerobic sequencing batch reactor: effects of operational parameters, COD: N ratio, and organic acid composition. International Journal of Hydrogen Energy. 2010;35:4092-102.

[24] Salminen EA, Rintala JA. Semi-continuous anaerobic digestion of solid poultry slaughterhouse waste: effect of hydraulic retention time and loading. Water Research. 2002;36:3175-82. [25] Zhang M-L, Fan Y-T, Xing Y, Pan C-M, Zhang G-S, Lay J-J. Enhanced biohydrogen production from cornstalk wastes with acidification pretreatment by mixed anaerobic cultures. Biomass and Bioenergy. 2007;31:250-4. [26] Fan Y-T, Zhang G-S, Guo X-Y, Xing Y, Fan M-H. Biohydrogen-production from beer lees biomass by cow dung compost. Biomass and Bioenergy. 2006;30:493-6.

[27] Immanuel G, Dhanusha R, Prema P, Palavesam A. Effect of different growth parameters on endoglucanase enzyme activity by bacteria isolated from coir retting effluents of estuarine environment. International Journal of Environmental Science \& Technology. 2006;3:25-34. [28] de Vrije T, Bakker RR, Budde MA, Lai MH, Mars AE, Claassen PA. Efficient hydrogen production from the lignocellulosic energy crop Miscanthus by the extreme thermophilic bacteria Caldicellulosiruptor saccharolyticus and Thermotoga neapolitana. Biotechnology for biofuels. 2009;2:12.

[29] Hansen C, Zhong J, Hansen J. Anaerobic Digestion of Dairy Processing Waste, Algae, and Grass in Pilot and Full Scale. Transactions of the ASABE. 2014;57:609-14.

[30] Aitken MD, Sobsey MD, Shehee M, Blauth KE, Hill VR, Farrell JB, et al. Laboratory evaluation of thermophilic-anaerobic digestion to produce Class A biosolids. 2. Inactivation of pathogens and indicator organisms in a continuous-flow reactor followed by batch treatment. Water Environment Research. 2005:3028-36. [31] Antonopoulou G, Stamatelatou K, Venetsaneas N, Kornaros M, Lyberatos G. Biohydrogen and methane production from cheese whey in a two-stage anaerobic process. Industrial \& Engineering Chemistry Research. 2008;47:5227-33. 
$334 \quad$ List of tables

335

336

337

338

339

340

341

342

343

344

345
Table 1- Characteristics of dairy processing waste (DPW)

\begin{tabular}{ll}
\hline Dairy Processing Waste (DPW) & \\
\hline $\mathrm{pH}$ & $4.5 \pm 0.6$ \\
Total COD (g/L) & $98.7 \pm 4.0$ \\
Soluble COD (g/L) & $75.6 \pm 2.6$ \\
Total Solids (TS, g/L) & $61.1 \pm 4.8$ \\
Volatile Solids (VS, g/L) & $55.3 \pm 3.7$ \\
Total Organic Carbon (TOC, g/L) & $24.8 \pm 3.3$ \\
Total nitrogen (g/L) & $4.06 \pm 1.21$ \\
$\mathrm{NH}_{3}-\mathrm{N}(\mathrm{g} / \mathrm{L})$ & $2.30 \pm 0.81$ \\
\hline
\end{tabular}


Table 2-Values of temperature, $\mathrm{pH}, \mathrm{HRT}$ and OLR in each experiment run

\begin{tabular}{ccccc}
\hline $\begin{array}{c}\text { Experiment run } \\
\text { number }\end{array}$ & $\begin{array}{c}\text { Temperature } \\
\left({ }^{\circ} \mathrm{C}\right)\end{array}$ & $\mathrm{pH}$ & HRT & OLR \\
(days) & & 1 & 98.7 \\
II & 40 or 60 & $4.0-4.5$ & 32.9 \\
III & 40 or 60 & $4.0-4.5$ & 5 & 19.74 \\
IV & 40 or 60 & $4.0-4.5$ & 1 & 98.7 \\
V & 40 or 60 & $4.8-5.3$ & 32.9 \\
VI & 40 or 60 & $4.8-5.3$ & 3 & 19.74 \\
VII & 40 or 60 & $4.8-5.3$ & 5 & 98.7 \\
VIII & 40 or 60 & $5.5-6.0$ & 1 & 32.9 \\
IX & 40 or 60 & $5.5-6.0$ & 3 & 19.74 \\
\hline
\end{tabular}


Table 3-Methane production performance in two-stage digestion

\begin{tabular}{ccccccc}
\hline HRT & OLR & Influent & COD Removal & $\mathrm{pH}$ inside & Methane Yield & Methane content \\
(days) & $(\mathrm{g} / \mathrm{l}-\mathrm{d})$ & $\mathrm{pH}$ & $(\%)$ & digester & $\left(\mathrm{ml} / \mathrm{g}-\mathrm{COD}_{\text {removed }}\right)$ & $(\%)$ \\
\hline 8 & 7.0 & $5.7 \pm 0.2$ & $53.4 \pm 0.3$ & $7.0 \pm 0.2$ & $168.8 \pm 3.2$ & $61.3 \pm 0.4$ \\
12 & 5.6 & $5.7 \pm 0.2$ & $61.2 \pm 0.8$ & $7.2 \pm 0.3$ & $170.4 \pm 1.8$ & $62.5 \pm 0.3$ \\
15 & 3.7 & $5.7 \pm 0.2$ & $73.1 \pm 1.2$ & $7.2 \pm 0.2$ & $178.1 \pm 2.9$ & $62.7 \pm 0.5$ \\
20 & 2.8 & $5.7 \pm 0.2$ & $75.7 \pm 0.6$ & $7.3 \pm 0.2$ & $145.2 \pm 3.2$ & $64.7 \pm 1.1$ \\
\hline
\end{tabular}


Table 4-Overall performance of two-stage digestion

\begin{tabular}{|c|c|}
\hline & $\begin{array}{l}\text { Overall two-stage } \\
\text { IBR digestion }\end{array}$ \\
\hline \multicolumn{2}{|l|}{ Hydrogen production unit } \\
\hline optimal HRT(days) & 3 \\
\hline $\mathrm{OLR}(\mathrm{g}-\mathrm{COD} / \mathrm{I}-\mathrm{d})$ & 32.9 \\
\hline optimal pH & 4.8-5.5 \\
\hline Temperature $\left({ }^{\circ} \mathrm{C}\right)$ & 60 \\
\hline hydrogen yield $\left(\mathrm{ml}^{-\mathrm{H}_{2}} / \mathrm{g}-\mathrm{COD}\right.$ removed $)$ & 160.7 \\
\hline hydrogen production rate $\left(\mathrm{ml}-\mathrm{H}_{2} / \mathrm{l}-\mathrm{d}\right)$ & 2358.3 \\
\hline COD removal (\%) & 44.6 \\
\hline \multicolumn{2}{|l|}{ Methane production unit } \\
\hline methane yield $\left(\mathrm{ml}^{-} \mathrm{CH}_{4} / \mathrm{g}-\mathrm{COD} \text { removed }\right)^{*}$ & 178.1 \\
\hline methane production rate $\left(\mathrm{ml}-\mathrm{CH}_{4} / \mathrm{l}-\mathrm{d}\right)$ & 483.3 \\
\hline COD removal $(\%)^{*}$ & 73.1 \\
\hline Overall gas production ( $\left.\mathrm{ml}-\mathrm{H}_{2}: \mathrm{ml}^{-}-\mathrm{CH}_{4} / \mathrm{COD}_{\text {loaded }}\right)^{*}$ & 71.7:61.0 \\
\hline Overall COD removal (\%) ${ }^{*}$ & 88.2 \\
\hline
\end{tabular}

351

*: Calculation based on 15 days HRT in the methane IBR.

352 
Table 5-Comparison of two-stage digestion to some other studies

\begin{tabular}{|c|c|c|c|c|}
\hline & $\begin{array}{l}\text { Two-stage IBRs } \\
\text { (present } \\
\text { study) }\end{array}$ & $\begin{array}{l}\text { Two-stage } \\
\text { CSTR+UASB[13] }\end{array}$ & $\begin{array}{l}\text { Two-stage } \\
\text { UASBs[31] }\end{array}$ & $\begin{array}{l}\text { Two-stage } \\
\text { UASBs[14] }\end{array}$ \\
\hline Substrate & DPW & $\begin{array}{l}\text { Cheese whey } \\
\text { powder }\end{array}$ & $\begin{array}{l}\text { Cheese } \\
\text { Whey }\end{array}$ & $\begin{array}{l}\text { Cassava } \\
\text { wastewater }\end{array}$ \\
\hline Temperature $\left({ }^{\circ} \mathrm{C}\right)$ & 60 & 37 & 35 & 55 \\
\hline HRT(days) & 3 & 0.25 & 1 & - \\
\hline $\mathrm{OLR}(\mathrm{g}-\mathrm{COD} / \mathrm{l}-\mathrm{d})$ & 32.9 & 182 & 47.4 & 12 \\
\hline \multicolumn{5}{|l|}{ Hydrogen production unit } \\
\hline Digester size (L) & 60 & 2 (CSTR) & 3 & 4 \\
\hline hydrogen yield $\left(\mathrm{ml}-\mathrm{H}_{2} / \mathrm{g}-\mathrm{COD}\right.$ removed $)$ & 160.7 & - & 41 & 169 \\
\hline hydrogen production rate $\left(\mathrm{ml}-\mathrm{H}_{2} / \mathrm{I}-\mathrm{d}\right)$ & 2358.3 & 25000 & 2510 & - \\
\hline COD removal (\%) & 44.6 & - & & 35 \\
\hline \multicolumn{5}{|l|}{ Methane production unit } \\
\hline Digester size (L) & 60 & 0.79 (UASB) & 15 & 24 \\
\hline methane yield $\left(\mathrm{ml}^{-} \mathrm{CH}_{4} / \mathrm{g}-\mathrm{COD} \text { removed }\right)^{*}$ & 178.1 & 210 & - & 164.8 \\
\hline methane production rate $\left(\mathrm{ml}-\mathrm{CH}_{4} / \mathrm{l}-\mathrm{d}\right)$ & 483.3 & - & - & - \\
\hline COD removal $(\%)^{*}$ & 73.1 & & & 72 \\
\hline $\begin{array}{l}\text { Overall gas production ( } \mathrm{ml}-\mathrm{H}_{2}: \mathrm{ml}^{-} \mathrm{CH}_{4} / \mathrm{COD} \\
\text { loaded) }\end{array}$ & 71.7:61.0 & - & - & - \\
\hline Overall COD removal (\%) ${ }^{*}$ & 88.2 & 82 & 94 & 86.4 \\
\hline
\end{tabular}


$358 \quad$ List of figures

359

360

361

362

363

364

365
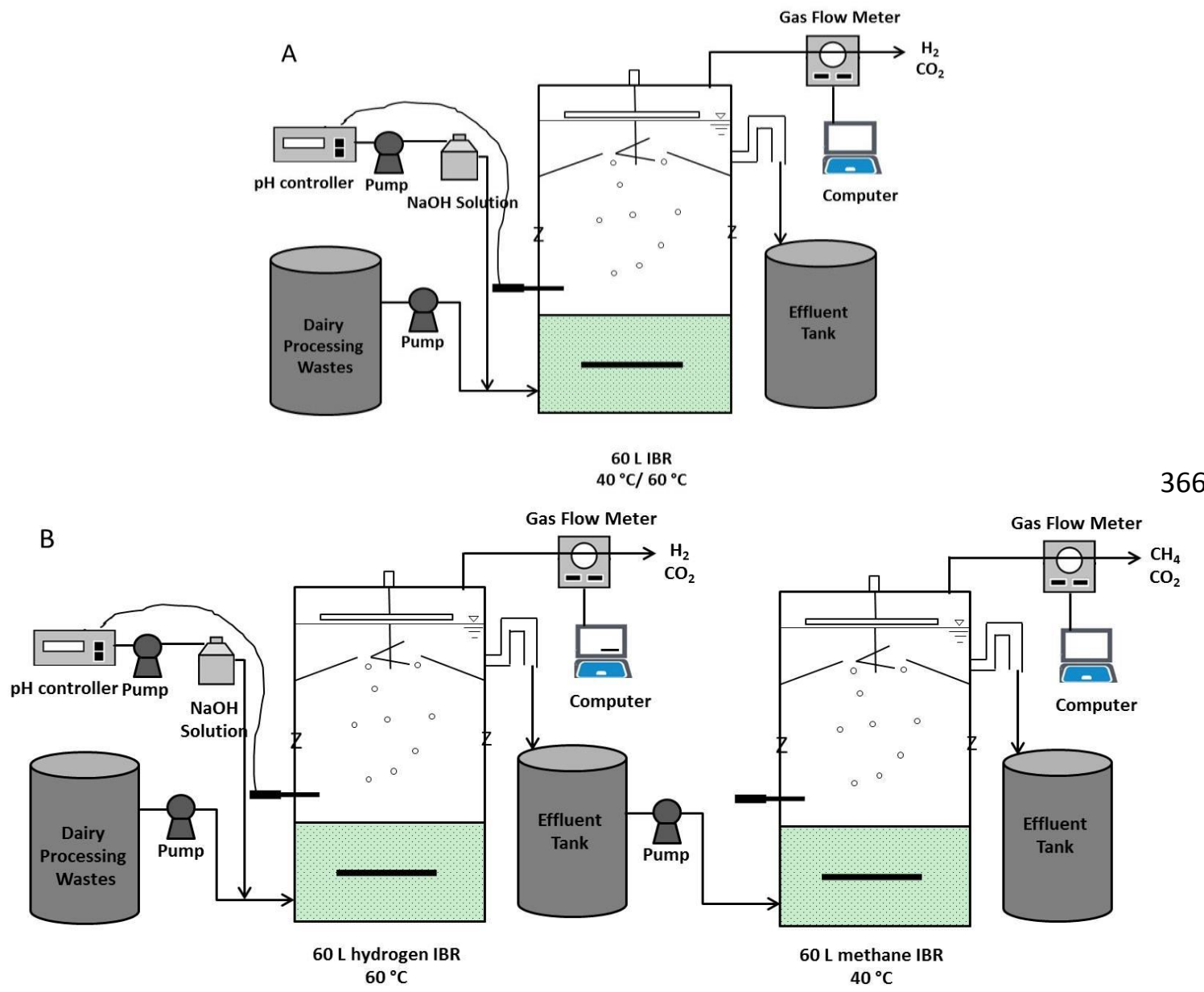

Figure 1-Schematic of single-stage and two-stage induced bed reactor (IBR) digestion. (A) single-stage IBR digestion. (B) two-stage IBR digestion. 

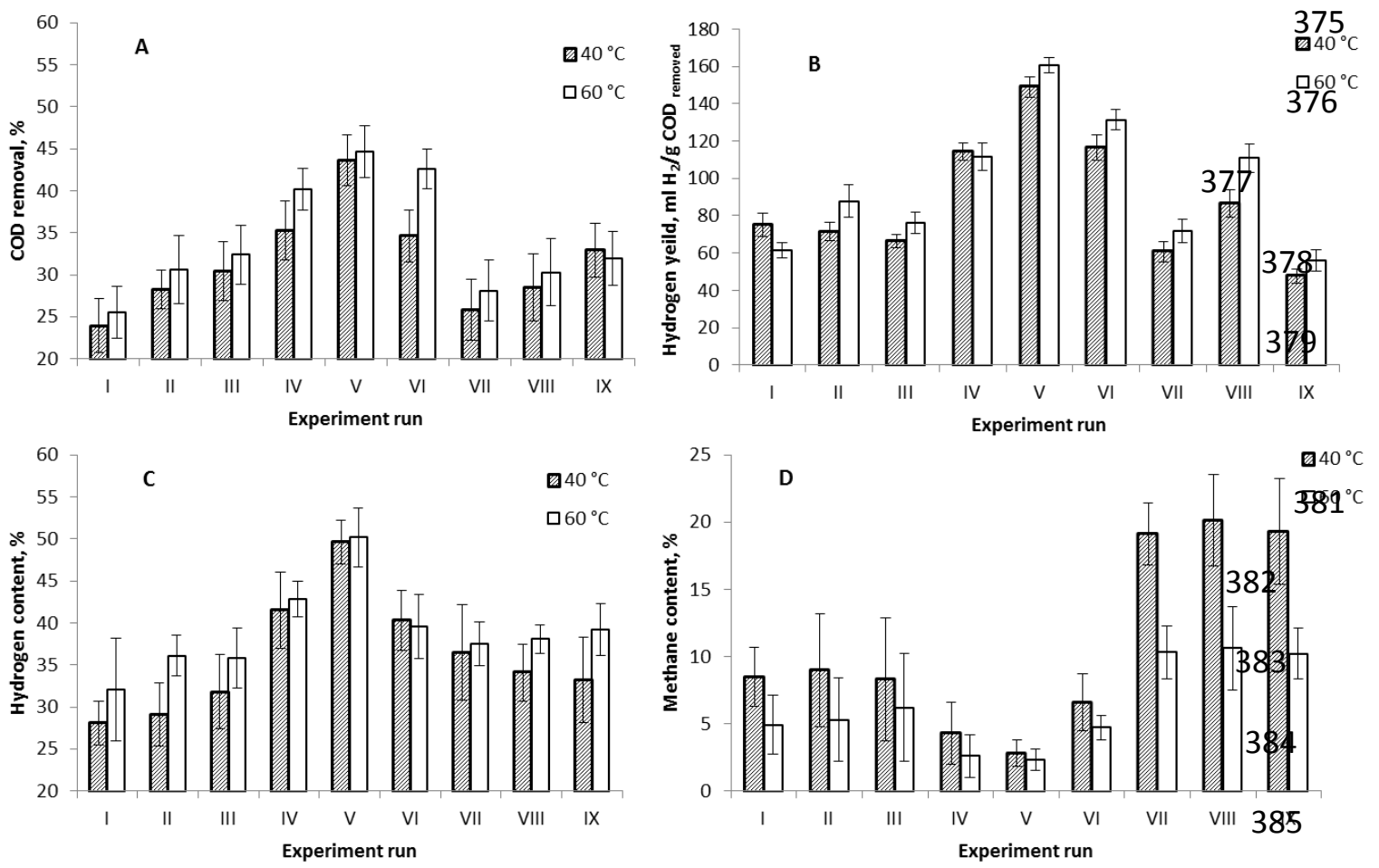

387 Figure 2-Results of (A) COD removals, (B) hydrogen yields, (C) hydrogen content and (D) methane content in nine experiment runs. Error bar represents standard deviation. 